\title{
Comparison of combined therapy with ultrasound-associated interferential current in healthy subjects
}

\author{
Comparação da terapia combinada com corrente interferencial associada ao ultrassom em \\ indivíduos saudáveis
}

Bárbara Caroline Royer ${ }^{1}$, Carla de Fátima Albuquerque ${ }^{1}$, Cecília Felix da Silva ${ }^{1}$, Gabriela Walker Zancanaro ${ }^{1}$, Gustavo Kiyosen Nakayama', Gladson Ricardo Flor Bertolini²

DOI 10.5935/2595-0118.20180011

\section{ABSTRACT}

BACKGROUND AND OBJECTIVES: Although used in the therapeutic field, there is a shortage of studies that evaluate combined therapy or the association of electrical currents with therapeutic ultrasound, the present study aimed to compare the two forms in healthy individuals, analyzing the pain, number of accommodations and current intensity.

METHODS: Thirty healthy volunteers took turns for three weeks in three groups. Nociception was evaluated by means of pressure and thermal stimuli in the lumbar spine and respective dermatomes. Then, the volunteer's dominant foot was submerged in cold water to evaluate the threshold of pain and its intensity. Shortly after, electroanalgesia (combined therapy, only current association with ultrasound, or placebo) was applied for 15 minutes. The application of the bipolar interferential current used a frequency of $4 \mathrm{kHz}$, and amplitude modulation frequency of $100 \mathrm{~Hz}$, with one electrode on L3 and the other on S1. When combined therapy was used, the ultrasound head $(1 \mathrm{MHz})$ played the role of the electrode positioned over the L5-S1 region, in continuous form, at a dose of $0.4 \mathrm{~W} / \mathrm{cm}^{2}$. The intensity of the initial and final current was evaluated, as well as the number of accommodations.

RESULTS: There was no significant difference between the pain thresholds of pressure and cold, but the combined therapy required more current intensity despite having a smaller number of accommodations.

CONCLUSION: None of the therapies produced a difference in pain thresholds, but the combined therapy had fewer accommodations.

Keywords: Analgesia, Pain measurement, Physical therapy modalities, Transcutaneous electric nerve stimulation, Ultrasonic therapy.

1. Universidade Estadual do Oeste do Paraná, Departamento de Fisioterapia, Cascavel, PR, Brasil. 2. Universidade de São Paulo, Faculdade de Medicina de Ribeirấo Preto, Ribeirão Preto, SP, Brasil.

Submitted in November 30, 2017.

Accepted for publication in February 07, 2018.

Conflict of interests: none - Sponsoring sources: none

Correspondence to

Rua Universitária, 2069 - Jardim Universitário

85819-110 Cascavel, PR, Brasil.

E-mail: gladsonricardo@gmail.com

(c) Sociedade Brasileira para o Estudo da Dor

\section{RESUMO}

JUSTIFICATIVA E OBJETIVOS: Apesar de utilizada no campo terapêutico, há escassez de estudos que avaliem a terapia combinada ou a associação de correntes elétricas ao ultrassom terapêutico. O objetivo deste estudo foi comparar as duas formas em indivíduos saudáveis, analisando o limiar de dor ao frio e à pressão, número de acomodaçôes e intensidade da corrente.

MÉTODOS: Trinta voluntários saudáveis revezaram em três grupos de forma cruzada durante três semanas. A nocicepção foi avaliada por meio de estímulos pressóricos e térmicos na coluna lombar e dermátomos. Em seguida, o voluntário teve seu pé submerso em água fria, e avaliado o limiar e a intensidade da dor. Logo após foi aplicado a eletroanalgesia (terapia combinada, apenas associação da corrente com ultrassom, ou placebo), por 15 minutos. Para corrente interferencial bipolar, foram utilizados frequência de $4 \mathrm{kHz}$ e frequência modulada pela amplitude de $100 \mathrm{~Hz}$, com um eletrodo sobre L3 e o outro sobre S1. Quando se utilizou a terapia combinada, o cabeçote do ultrassom $(1 \mathrm{MHz})$ fez o papel do eletrodo posicionado sobre a região de L5-S1, na forma contínua, com dose de $0,4 \mathrm{~W} / \mathrm{cm}^{2}$. Foi avaliada a intensidade da corrente inicial e final, além do número de acomodaçóes.

RESULTADOS: Não houve diferença significativa entre os limiares dolorosos à pressão e ao frio, mas a terapia combinada, apesar de ter apresentado menor número de acomodaçóes, necessitou maior intensidade da corrente.

CONCLUSÁO: Nenhuma das terapias produziu diferença nos limiares dolorosos, mas a terapia combinada apresentou menor número de acomodações.

Descritores: Analgesia, Estimulação elétrica nervosa transcutânea, Mensuração da dor, Modalidades de fisioterapia, Terapia por ultrassom.

\section{INTRODUCTION}

Nociception can be defined as the mechanism responsible for protecting the body against injuries, whereas acute pain occurs when it fails in preventing the injury, with the transformation of the nociceptive activity in conscious pain. Adaptations in the nociceptive threshold are critical for the development of chronic pain that is produced by the reorganization of the brain matrix ${ }^{1,2}$. The interferential current is an electrostimulation that basically aims at the reduction of pain. It is generated from two alternating currents of medium frequency, which by interference, generate a re- 
sultant with the average frequency between the two initial ones ${ }^{3}$. However, the interferential can be applied in other clinical conditions, such as muscle re-education, strengthening, and reduction of edema ${ }^{4}$. One of the main characteristics of the interferential current is to generate amplitude modulation frequency (AMF), stimulating the depolarization of afferent fibers as a low frequency current ${ }^{5}$.

Another modality that also aims at pain control is the therapeutic ultrasound that usually works with $1 \mathrm{MHz}$ and $3 \mathrm{MHz}$ frequencies, with a deep or superficial action, respectively. It is commonly used in clinical practice, also with the objective of speed up the metabolic and inflammatory processes in cells and tissues ${ }^{6,7}$. These two modalities can be combined into one single therapy to amplify the therapeutic results, called combination therapy ${ }^{8}$. Thus, it is necessary to have one fixed electrode and one mobile (the ultrasound header), and its simultaneous use with low to medium current. This modality increments the effects of the therapy, with reports that there is no need to work with high currents. On the other hand, over time, the patient has the sensation that the current increases ${ }^{9}$, in contrast to what is usually observed with the use of currents aiming at electroanalgesia, which characteristic is the accommodation when there is a repetitive application of the same stimulus, thus decreasing the physiological response $^{10}$. This form of therapy, however, is still little explored by the scientific literature. Regarding the intensity for the electrostimulation, the basis is generally perception capacity of the individual, that is, this is an abstract sensation ${ }^{11}$.

Due to the scarcity of studies addressing the combination therapy, the objective of the present study was to compare the combination therapy (jointly therapies) and the interferential current associated with ultrasound (isolated therapies applied simultaneously) in healthy individuals, analyzing the cold pain threshold and pressure, number of accommodations and current intensity.

\section{METHODS}

This is a cross-sectional, randomized and quantitative study. The sample was composed of 30 volunteers, students of the State University of the West of Paraná (UNIOESTE), healthy, without any type of pain in the assessed region. There were 22 female volunteers and 8 male volunteers with ages between 18 and 33 years (average of $21.37 \pm 3.16$ years), weighting $62.82 \pm 10.05 \mathrm{~kg}$, a height of $1.68 \pm 0.08 \mathrm{~m}$, and body mass index (BMI) of $22.27 \pm 3.05$. All participants in the study signed the Free and Informed Consent form (FICT) before the beginning of the study.

The subjects performed the same activities, randomly, in three consecutive weeks, that is, each individual was chosen to receive one current in each week. The three currents used were the combination therapy (CT - ultrasound + interferential current), associated therapy (AS- ultrasound and interferential current) and the placebo treatment (PT) in which the volunteers did not receive any type of electrostimulation.

Individuals with any contraindication to electrostimulation or therapeutic ultrasound, such as the use of a pacemaker, metallic synthesis, sensation alterations, hemorrhagic processes, as well as the contraindication to cold therapy (cold hypersensitivity and hives) were excluded.
Based on the initial assessment data of the pressure threshold, with a standard deviation of 328 , the difference to be detected of 210 , a significance level of $5 \%$, with the size of the sample used, the power of the test was of $80 \%$.

\section{Nociceptive evaluation}

The nociception was evaluated using pressure and thermal stimuli in the lumbar spine and respective dermatomes. To evaluate the pain threshold to pressure it was used a pressure algometer (Kratos), with a tapered tip, applied on the paravertebral region $\left(3 \mathrm{~cm}\right.$ lateral to the spinous process) of the $5^{\text {th }}$ lumbar vertebra (L5). It was also evaluated the pressure threshold in the L4 and L5 dermatome corresponding region in the lower limb. After the measurements, the force (gf) needed to cause the painful stimulus was recorded.

Then, the volunteer submerged the dominant foot in a bucket with water controlled at $5^{\circ} \mathrm{C}$, up to the intermalleolar region. The volunteer was requested to indicate the moment when it felt pain and this moment was timed. This was considered the cold pain threshold. However, the subject kept the limb immersed in cold water, until completing 60 seconds, and after this period, the subject was asked to indicate on the visual analog scale (VAS), the intensity of the pain felt during the 30 seconds. The evaluations were performed before the electrostimulation (AV1), right after the therapy (AV2), and 30 minutes after (AV3).

\section{Electrostimulation protocol}

Soon after the initial nociceptive evaluation (AV1), the subject went to the therapy application, which lasted 15 minutes. At the beginning of the protocol, the current intensity was raised until the sensation of intense paresthesia, but without reaching the nociceptive threshold. During the electric stimulation, the time was counted until the subject (previously guided) indicated the reduction of the paresthesia sensation of the current (accommodation threshold). Then, the intensity was adjusted to return to the initial paresthesia sensation. The number of accommodations was recorded in all moments when the volunteer reported such need, and the current intensity was marked at the beginning and at the end of the therapy.

For the application of the CT we used the ultrasound header $(1 \mathrm{MHz})$ in the continuous form, with a dose of $0.4 \mathrm{~W} / \mathrm{cm}^{2}$, which played the role of an electrode, with slow and rhythmic movements on the L3-L5 region, while only one electrode of the interferential current in the bipolar form, $4 \mathrm{kHz}, 100 \mathrm{~Hz}$ AMF, were placed on the of $S 1$ region.

When the AT was used, an electrode was placed on the L3 region and the other on $\mathrm{S} 1$, the intensity was strong, however, not painful. Yet, in AT the ultrasound header was placed between L3 and S1. Both therapies were used simultaneously, with the same parameters of the combination therapy.

There was no type of electrostimulation in the PT, just the placement of the ultrasound header with gel, performing circular movements onto the lumbar region for 15 minutes, simulating the therapy.

This study it was approved by the Research Ethics Committee of UNIOESTE, with report number 1.696.921. 


\section{Statistical analysis}

The data are presented in average and standard deviation, or median and quartiles. In order to evaluate data normality, we used the Shapiro-Wilk test, and for the comparison of the results obtained in the evaluation with the pressure algometer and current intensity we used the unidirectional ANOVA with Bonferroni post-test. The Friedman test was used for the evaluations performed at low temperature, and for the accommodations, we used the Wilcoxon test. In all the cases, the accepted level of significance was $5 \%$.

Table 1. The pain threshold to the pressure of the L5 region (lumbar) and the L4 and L5 dermatomes, in the evaluations of combined and associated currents and placebo

\begin{tabular}{|c|c|c|c|}
\hline Region & Therapies & Evaluations & Pressure threshold (gf) \\
\hline \multirow[t]{3}{*}{ L5 (lumbar) } & CT & $\begin{array}{l}\text { AV1 } \\
\text { AV2 } \\
\text { AV3 }\end{array}$ & $\begin{array}{c}560 \pm 218.15 \\
658.66 \pm 319.07 \\
659.66 \pm 275.26\end{array}$ \\
\hline & AT & $\begin{array}{l}\text { AV1 } \\
\text { AV2 } \\
\text { AV3 }\end{array}$ & $\begin{array}{l}696.66 \pm 420.19 \\
642.33 \pm 347.68 \\
678.33 \pm 278.03\end{array}$ \\
\hline & PT & $\begin{array}{l}\text { AV1 } \\
\text { AV2 } \\
\text { AV3 }\end{array}$ & $\begin{array}{c}669.33 \pm 345.21 \\
688.66 \pm 297.26 \\
648 \pm 244.26\end{array}$ \\
\hline \multirow[t]{3}{*}{ L4 (dermatome) } & CT & $\begin{array}{l}\text { AV1 } \\
\text { AV2 } \\
\text { AV3 }\end{array}$ & $\begin{array}{c}509.8 \pm 226.83 \\
615.33 \pm 196.76 \\
634.46 \pm 304.34\end{array}$ \\
\hline & AT & $\begin{array}{l}\text { AV1 } \\
\text { AV2 } \\
\text { AV3 }\end{array}$ & $\begin{array}{c}565.2 \pm 331.39 \\
604.66 \pm 407.47 \\
543 \pm 189.53\end{array}$ \\
\hline & PT & $\begin{array}{l}\text { AV1 } \\
\text { AV2 } \\
\text { AV3 }\end{array}$ & $\begin{array}{c}596.76 \pm 285.49 \\
597.2 \pm 275.06 \\
594.86 \pm 287.62\end{array}$ \\
\hline \multirow[t]{3}{*}{ L5 (dermatome) } & CT & $\begin{array}{l}\text { AV1 } \\
\text { AV2 } \\
\text { AV3 }\end{array}$ & $\begin{array}{c}803 \pm 496.72 \\
880.13 \pm 478.70 \\
940.06 \pm 490.93\end{array}$ \\
\hline & AT & $\begin{array}{l}\text { AV1 } \\
\text { AV2 } \\
\text { AV3 }\end{array}$ & $\begin{array}{c}1029.86 \pm 666.04 \\
1039.66 \pm 825.18 \\
1057.7 \pm 886.26\end{array}$ \\
\hline & PT & $\begin{array}{l}\text { AV1 } \\
\text { AV2 } \\
\text { AV3 }\end{array}$ & $\begin{array}{c}866.56 \pm 333.77 \\
869.56 \pm 444.61 \\
997 \pm 503.73\end{array}$ \\
\hline
\end{tabular}

$\overline{\mathrm{AV} 1}$ = first evaluation, $\mathrm{AV} 2$ = second evaluation, $\mathrm{AV} 3=$ third evaluation. $\mathrm{TC}=$ combined therapy, YOU = associated therapy, PT = placebo therapy.

\section{RESULTS}

In the comparison of the pain threshold to the pressure between AV1, AV2, and AV3, no significant difference was found when compared with the L5 (Lumbar) regions and the L4 and L5 dermatomes $(\mathrm{F}=0.5015 ; \mathrm{p}=0.8553, \mathrm{~F}=0.549 ; \mathrm{p}=0.8198$ and $\mathrm{F}=0.9719 ; \mathrm{p}=0.5409$, respectively) (Table 1 ).

Also, for the cold pain threshold and VAS, there was no significant difference in all the groups (Table 2).

There was a significant difference in the number of accommodations between the combined and associated currents $(\mathrm{p}=0.0054)$ (CT $\mathrm{Md}=1.5 ; \mathrm{Q} 1=1 ; \mathrm{Q} 3=3$ and $\mathrm{AT} \mathrm{Md}=3 ; \mathrm{Q} 1=2 ; \mathrm{Q} 3=4$, respectively). In the evaluation of the combined and associated current intensities, initial (CT 62.96 \pm 24.34 ; AT 35.3 \pm 20.42 ) and final (CT 74.36 \pm 23.77 ; AT 72.43 \pm 27.40$)$, there was a significant difference $(\mathrm{p}<0.0001)$, with differences between the CT with initial ATs, and initial and final AT.

\section{DISCUSSION}

In spite of being a resource used in the clinical practice, the CT is little explored in scientific research, we tried in the present study to evaluate the effects of cold and pressure induced pain, as well as the own characteristics of the current, such as the necessary intensity for therapy and the number of accommodations. The main justification for the CT is that the beneficial effects of the two modalities can be achieved at the same time, and even the possibility of an amplifying effect of one therapy with the other, and time efficiency for the therapist and the patient ${ }^{12}$.

No significant difference between the pressure and cold-induced pain threshold was found in the L5 (lumbar) and in the L4 and L5 dermatomes regions, regardless the therapy delivery (combined, associated or placebo). This corroborates the data from another study that used as an electrostimulation method the transcutaneous electrical nerve stimulation, which similarly found no difference in pressure and cold pain thresholds. This study, however, evaluated the thenar and hypothenar region using the transcutaneous electrical nerve stimulation as a form of current ${ }^{13}$. Silva et al. ${ }^{11}$ also comparing different interferential base frequencies, did not observe rising effects on the pressure and cold pain induced threshold. Similarly, Claro et al. ${ }^{14}$ did not evidence alterations in the thresholds when

Table 2. The cold pain threshold and the visual analog scale of the L5 region (lumbar) and the L4 and L5 dermatomes, in the evaluations of combined and associated currents and placebo

\begin{tabular}{|c|c|c|c|c|c|c|c|}
\hline \multirow[t]{2}{*}{ Therapies } & \multirow[t]{2}{*}{ Evaluations } & \multicolumn{3}{|c|}{ Cold pain threshold (seconds) } & \multicolumn{3}{|c|}{ Visual analog scale } \\
\hline & & $\mathrm{Md}$ & Q1 & Q3 & Md & Q1 & Q3 \\
\hline CT & $\begin{array}{l}\text { AV1 } \\
\text { AV2 } \\
\text { AV3 }\end{array}$ & $\begin{array}{c}14,5 \\
10,5 \\
14\end{array}$ & $\begin{array}{c}8,25 \\
7 \\
7,25\end{array}$ & $\begin{array}{c}41,25 \\
59,75 \\
53\end{array}$ & $\begin{array}{c}6,5 \\
7 \\
6,75\end{array}$ & $\begin{array}{c}4,57 \\
5,2 \\
5\end{array}$ & $\begin{array}{l}7,97 \\
7,72 \\
8,37\end{array}$ \\
\hline AT & $\begin{array}{l}\text { AV1 } \\
\text { AV2 } \\
\text { AV3 }\end{array}$ & $\begin{array}{l}14 \\
12 \\
18\end{array}$ & $\begin{array}{c}7,25 \\
8 \\
9\end{array}$ & $\begin{array}{c}32,25 \\
27 \\
43,75\end{array}$ & $\begin{array}{c}6 \\
6,25 \\
6\end{array}$ & $\begin{array}{c}4,5 \\
5 \\
4,5\end{array}$ & $\begin{array}{c}7 \\
7,5 \\
7,37\end{array}$ \\
\hline
\end{tabular}

Av1 = first evaluation; Av2 = second evaluation; Av3 = third evaluation; Md = median; Q1 = first quartile; $\mathrm{Q} 3=$ third quartile; CT = combination therapy; AT = associated therapy; PT = placebo therapy. 
varying the interferential AMF. It is worth mentioning that in all the studies the individuals submitted to the evaluations were healthy, that is, the stimulation purpose was to increase the pain threshold and not necessarily to produce analgesia, and we should keep in mind that pain assessment is a subjective process, with differences in physical, psychological and social nature ${ }^{15}$. This was considered the major limitation of the present study and a suggestion to others to focus on patients with existing painful pictures.

In contrast to this study, other authors used the tetrapolar method ${ }^{16}$ in which four electrodes are placed, and the medium frequency currents are modulated within the patient; in this case, there was a change in the pain threshold in the dermatomes. However, it differs from what is commonly applied in the combination therapy, in which an electrode is placed directly on the patient, and the ultrasonic transducer functions as the other electrode, that is, in a bipolar way.

Therapeutic ultrasound is another modality commonly used in the clinical practice with the purpose to increase the local metabolism and with this to speed up chemical processes, such as inflammation and repair ${ }^{17}$. But, also by thermal and non-thermal actions, it can reduce painful pictures due to the increase of the depolarization threshold of the nerve fibers ${ }^{18-20}$.

Two studies presented positive results in patients with fibromyalgia treated with the CT. Almeida et al. ${ }^{21}$ used this modality in patients with fibromyalgia, with interferential parameters of $4 \mathrm{KHz}, 100 \mathrm{~Hz}$ of AMF, with intensity in the sensation threshold, and ultrasound of $1 \mathrm{MHz}$, pulsed dose of $2.5 \mathrm{~W} / \mathrm{cm}^{2}$ (without specifying the work cycle), and observed that after 12 sessions there was an improvement in sleep (subjectively and objectively), morning fatigue, in pain intensity, and number of tender points. A similar result was observed by Moretti et al. ${ }^{22}$ in which they observed that one or two weekly therapies (with parameters similar to the previous study, but with the ultrasound cycle specified at $20 \%$ ), were effective in reducing pain, and improving the quality of life and sleep. It should be noted that in this study, the volunteers did not have pain, and the therapy parameters were slightly different from those already described, not for the interferential, but for the ultrasound, which was continuous with a dose of $0.4 \mathrm{~W} / \mathrm{cm}^{2}$. That is, even though in the study of Moretti et al. ${ }^{22}$, the temporal average dose (not cited) has been of $0.5 \mathrm{~W} /$ $\mathrm{cm}^{2}$, the present study used a slightly smaller power density, but, based on the proposal to use non-thermal ultrasound doses?

Regarding the intensity of the combination and associated therapies, there was a significant difference between both. The associated therapy started with lower intensity, and over time there were accommodations requiring the increase in current intensity. The combination therapy started with a higher intensity, occurring fewer accommodations, leading to a lower final intensity. However, in contrast to the literature ${ }^{9}$, we observed that the combination therapy, although producing a fewer number of accommodations, has also presented such phenomenon, including starting with an intensity higher to that observed when the therapies merely overlapped.

\section{CONCLUSION}

There was no significant difference between the pain thresholds but between the intensity and accommodation of the currents. The combination therapy, although presenting a fewer number of accommodations also produced this phenomenon, and required, initially, a higher current intensity.

\section{REFERENCES}

1. Rocha CS, Lanferdini FJ, Kolberg C, Silva MF, Vaz MA, Partata WA, et al. Interferentia therapy effect on mechanical pain threshold and isometric torque after delayed onset muscle soreness induction in human hamstrings. J Sports Sci. 2012;30(8):733-42.

2. Baliki MN, Apkarian AV. Nociception, pain, negative moods, and behavior selection. Neuron. 2015;87(3):474-91.

3. Artioli DP, Bertolini GR. Corrente interferencial vetorial: aplicação, parâmetros e resultados. Rev Bras Clin Méd. 2012;10(1):51-6.

4. Shanahan C, Ward AR, Robertson VJ. Comparison of the analgesic efficacy of in terferential therapy and transcutaneous electrical nerve stimulation. Physiotherapy. 2006;92(4):247-53.

5. Fuentes JP, Armijo Olivo S, Magee DJ, Gross DP. Effectiveness of interferential current therapy in the management of musculoskeletal pain: a systematic review and meta-analysis. Phys Ther. 2010;90(9):1219-38.

6. Warden SJ. A new direction for ultrasound therapy in sports medicine. Sport Med 2003;33(2):95-107.

7. Wong RA, Schumann B, Townsend R, Phelps CA. A survey of therapeutic ultrasound use by physical therapists who are orthopaedic certified specialists. Phys Ther. 2007;87(8):986-94.

8. Ricci NA, Dias CN, Driusso P. The use of electrothermal and phototherapeutic methods for the treatment of fibromyalgia syndrome: a systematic review. Rev Bras Fisioter. 2010;14(1):1-9.

9. Aragão AC. Análise da atividade do sistema nervoso autônomo em pacientes com dor miofascial tratados com terapia combinada. Universidade do Vale do Paraíba; 2008.

10. Guerra TE, Bertolini GR. Efeitos da variaçăo da rampa de entrega do $\Delta \mathrm{F}$ sobre a acomodação da corrente interferencial em mulheres saudáveis. Rev Dor. 2012;13(1):25-9.

11. Silva DO, Spironello A, Andretta G, Broetto GS, Jaskowiak JL, Bertolini GR. Corrente interferencial no limiar de dor induzida à pressão e ao frio, nas frequências de 2 kHz, 4 kHz e 8 kHz. ConsSaude. 2015;14(2):222-8.

12. Sant'Ana EM. Fundamentaçăo teórica para terapia combinada HECCUS - Ultrassom e Corrente Aussie no tratamento da lipodistrofia ginóide e da gordura localizada. Rev Bras Ciência Estética. 2010;1(1):1-15.

13. Schulz AP, Chao BC, Gazola F, Pereira GD, Nakanishi MK, Kunz RI, et al. Transcutaneous electrical nerve stimulation action on pressure-induced pain threshold. Rev Dor. 2011;12(3):231-4.

14. Claro AO, Kanezawa BA, Camargo M, Paes VM, Portolez JL, Bertolini GR. Pressure and cold pain threshold in healthy subjects undergoing interferential current at different amplitude modulated frequencies. Rev Dor. 2014;15(3):178-81.

15. Oliveira P, Monteiro P, Coutinho M, Salvador MJ, Costa ME, Malcata A. Qualidade de vida e vivência da dor crônica nas doenças reumáticas. Acta Reum Port. 2009;34(3):511-9.

16. Fiori A, Cescon CL, Galesky JD, Santos TA, Brancalhăo RM, Bertolini GR. Comparison between bipolar and tetrapolar of the interferential current in nociceptive threshold, accommodation and pleasantness in healthy individuals. Eur J Physiother. 2014;16(4):201-5.

17. Bruning MC, Silva DP, Anguera MG, BErtolini GR. Ultrassom terapêutico no tratamento da lesăo muscular: revisăo sistemática. Rev Pesqui Fisioter. 2016;6(4):455-61.

18. Ahmadi F, McLoughlin IV, Chauhan S, ter-Haar G. Bio-effects and safety of low-intensity, low-frequency ultrasonic exposure. Prog Biophys Mol Biol. 2012;108(3):11938.

19. ter Haar G. Ultrasound bio-effects and safety considerations. Front Neurol Neurosci. 2015;36:23-30.

20. Martignano CC, Silva LI, Meireles A, Rocha BP, Rosa CT, Bertollini GR. Avaliação do ultrassom sobre a hiperalgesia e o edema em joelhos de rato Wistar e interferências de um inibidor de opioides endógenos. Fisioter Bras. 2013;14(4):289-93.

21. Almeida TF, Roizenblatt S, Benedito-Silva AA, Tufik S. The effect of combined therapy (ultrasound and interferential current) on pain and sleep in fibromyalgia. Pain. 2003;104(3):665-72.

22. Moretti FA, Marcondes FB, Provenza JR, Fukuda TY, Vasconcelos RA, Roizenblatt S. Combined therapy (ultrasound and interferential current) in patients with fibromyalgia: once or twice in a week? Physiother Res Int. 2012;17(3):142-9. 